GEN 02133

\title{
Molecular cloning of the genome of human spumaretrovirus
}

(Foamy virus; reverse transcriptase; recombinant DNA; AIDS; HIV; long terminal repeat; embryonic lung)

\author{
A. Rethwilma, G. Darai ${ }^{b}$, A. Rósen ${ }^{b}$, B. Maurer ${ }^{a}$ and R.M. Flügel ${ }^{a}$ \\ ${ }^{a}$ Institute of Virus Research, German Cancer Research Center, 6900 Heidelberg (F.R.G.) and ${ }^{b}$ Institut für Medizinische Virologie \\ der Universität, 6900 Heidelberg (F.R.G.) Tel. (6221) 56-3008
}

Received 25 July 1987

Accepted 25 August 1987

\section{SUMMARY}

DNA of human spumaretrovirus (HSRV) was cloned from both cDNA and from viral DNA into phage $\lambda$ and bacterial plasmid vectors. The recombinant plasmids harboring viral DNA were characterized by Southern blot hybridization and restriction mapping. Physical maps were constructed from cDNA and found to be colinear with the restriction maps obtained from viral DNA. The recombinant clones isolated contained viral DNA inserts which range in size from $2.2 \mathrm{~kb}$ to $15.4 \mathrm{~kb}$. The recombinant clones allowed to construct a physical map of the complete HSRV provirus of $12.2 \mathrm{~kb}$.

\section{INTRODUCTION}

Spumaretroviruses (foamy viruses) have been known for many years. They have been isolated from many species including man (Hooks and Hooks, 1981). It was particularly D.C. Gajdusek and his group who succeeded in isolating many simian foamy viruses during their classical experiments on

Correspondence to: Dr. R.M. Flügel, Institut für Virusforschung, Deutsches Krebsforschungszentrum, Im Neuenheimer Feld 280, 6900 Heidelberg (F.R.G.) Tel. (6221)484-611.

Abbreviations: bp, base pair(s); cDNA, DNA complementary to viral RNA; dNTP, deoxynucleoside triphosphate; EtdBr, ethidium bromide; HEL, human embryonic lung; HIV, human immunodeficiency virus; HSRV, human spumaretrovirus; kb, kilobase(s) or $1000 \mathrm{bp}$; LTR, long terminal repeat; nt, nucleotide(s); SDS, sodium dodecyl sulfate; SSC, $0.15 \mathrm{M} \mathrm{NaCl}, 0.015$ $\mathrm{M} \mathrm{Na}_{3} \cdot$ citrate, $\mathrm{pH} 7.0 ; \mathrm{TKM}, 0.05 \mathrm{M}$ Tris $\cdot \mathrm{HCl}, 0.025 \mathrm{M} \mathrm{KCl}$, $0.0025 \mathrm{M} \mathrm{MgCl}_{2}, \mathrm{pH}$ 7.4.
Kuru and slow virus infections (Rogers et al., 1967; Gajdusek, 1977). Epidemiological data indicate a natural prevalence of foamy virus infection among men in East Africa (Muller et al., 1980). Foamy viruses have been found in patients with various diseases (Weiss et al., 1982). In cell culture, foamy viruses replicate only poorly, but cause a cytopathogenic effect with multinucleated giant-cell formation concomitant with typical vacuolization in a wide range of cells (Hooks and Hooks, 1981). They have been classified as a third subfamily of retroviridae and termed spumaviruses. Since the molecular biology of these viruses is virtually unknown, we molecularly cloned spumaretroviral DNA. As starting material for cloning, either DNA complementary to the HSRV genome or viral DNA from the genomic DNA of HSRV-infected human cells was prepared. The molecular clones of HSRV DNA will facilitate further studies on the structure and function of HSRV genome and its gene products. 


\section{MATERIALS AND METHODS}

\section{(a) Cells and viruses}

HEL cells were grown as described (Flugel et al., 1987) and HSRV was kindly provided by Dr. P. Loh (Loh and Ang, 1981). Virus was propagated by mixing infected HEL cells with uninfected growing HEL cells at a ratio of 1:4 (Neumann-Haefelin et al., 1983). For in vitro labeling of viral RNA, 16.5 $\mu \mathrm{Ci}\left[{ }^{3} \mathrm{H}\right.$ ] uridine (spec. act. $38 \mathrm{Ci} / \mathrm{mmol}$ ) per $\mathrm{ml}$ of culture medium was added. HSRV virions were clarified from cell supernatants by ultracentrifugation on days 2-5 after infection when the cytopathic effect was almost complete. Virus was resuspended in TKM buffer (Obara et al., 1971) and stored at $-20^{\circ} \mathrm{C}$ until further processing.

\section{(b) Virus purification and synthesis of HSRV cDNA}

HSRV was purified by centrifuging twice through a 20-60\% sucrose gradient in TKM buffer for $4 \mathrm{~h}$ at $100000 \times g$ in a SW41 rotor (Beckmann). Density fractions of $1.155-1.175 \mathrm{~g} / \mathrm{ml}$ shown to have maximum reverse transcriptase activity and in addition, to contain ${ }^{3} \mathrm{H}$-labeled RNA, were used for synthesis of viral cDNA.

For first-strand synthesis the method of Rothenberg and Baltimore (1976) was modified. The reaction volume of $500 \mu l$ contained $50 \mathrm{mM}$ Tris $(\mathrm{pH}$ 8.3), $8 \mathrm{mM} \mathrm{MgCl} 2,0.4 \mathrm{mM} \mathrm{MnCl}, 100 \mathrm{mM} \mathrm{KCl}$, $1 \mathrm{mM}$ dithiothreitol, $1 \mathrm{mM}$ of each $\mathrm{dNTP}, 0.01 \%$ $\mathrm{NP} 40,75 \mu \mathrm{g} / \mathrm{ml}$ oligo(dT) $)_{12}$ primer (Boehringer Mannheim), and $30 \mu \mathrm{g} / \mathrm{ml}$ oligodeoxynucleotide primers (provided by Dr. John Taylor) and an appropriate amount of virus. The reaction was carried out at $37^{\circ} \mathrm{C}$ for $20 \mathrm{~h}$. After treatment with SDS and proteinase $K$ the primary product was extracted with phenol-chloroform, and precipitated with ethanol. For synthesis of the second strand the procedure of Gubler and Hoffmann (1983) was followed. The final product was labeled according to Rigby et al. (1977), using $100 \mu \mathrm{Ci}$ each of the four $\left[\alpha-{ }^{32} \mathrm{P}\right] \mathrm{dNTPs}$, and used as probe for molecular hybridization.

\section{(c) Molecular cloning of viral cDNA}

Stock-frozen virus was used directly for synthesis of double-stranded HSRV cDNA. In two separate sets of experiments, cDNA was cut either with EcoRI or with HindIII, ligated to the corresponding sites of the phage vector $\lambda$ NM1149 (Murray, 1983) and packaged (Hohn, 1979). Recombinant phages were selected by plating on Escherichia coli POP13b (Murray, 1983). HSRV-positive clones were identified by filter hybridization using [ $\left.{ }^{32} \mathbf{P}\right]$ cDNA made from sucrose-gradient-purified virions as described above.

Out of 5000 recombinant clones, 180 hybridized to [ ${ }^{32} \mathrm{P}$ ]cDNA when using EcoRI-cut cDNA. Cloning efficiency using HindIII-digested cDNA was $10 \%$ (five out of 50 recombinant clones hybridized). DNAs from clones $\lambda$ HSRV-EcoRI 1 to 30 that gave strong hybridization signals, and DNA from clones 2HSRV-HindIII 1 to 5 that hybridized positively were prepared according to standard protocols (Maniatis et al., 1982). Insert DNAs from clones $\lambda$ HSRV-EcoRI 1 to 30 were purified by $0.8 \%$ agarose gel electrophoresis and recloned into the $E c o \mathrm{RI}$ sites of the plasmid vector pACYC184 (Chang and Cohen, 1978). Selection, amplification, and purification of the recombinants were carried out as described previously (Maniatis et al., 1982). HSRVpositive clones were identified by hybridization using separately synthesized [ $\left.{ }^{32} \mathrm{P}\right] \mathrm{cDNA}$ as probe. The plasmid clone pyHSRV-E-D2 was characterized in detail. DNA inserts from clones $\lambda$ HSRV-HindIII 1 to 5 were inserted into the HindIII sites of the vector pAT153 (Twigg and Sheratt, 1980), [ $\left.{ }^{32} \mathrm{P}\right] \mathrm{cDNA}$ was used to identify HSRV-positive clones, and clone pHSRV-H-C55 was further characterized.

\section{(d) Molecular cloning of viral DNA}

BamHI-digested high- $M_{\mathrm{r}}$ DNA $(0.5 \mu \mathrm{g})$ from HSRV-infected HEL cells was ligated with Bam HIdigested DNA from vector $2 \mathrm{EMBL} 4$ (Frischauf et al., 1983). DNA was packaged and recombinant phages were plated on E. coli NM539 (Frischauf et al., 1983). Out of $3 \times 10^{4}$ recombinant clones that were screened, two recombinant clones were identified to bear HSRV-specific sequences by filter hybridization with nick-translated DNA from pyHSRV-E-D2. The two recombinant phage clones were plaque-purified and re-screened. Insert DNA $(15.4 \mathrm{~kb})$ was extracted from low-melting-point agarose and recloned into the BamHI sites of the plasmid vector pSP65 (Melton et al., 1984) and the 
clone designated pSPHSRV-B-C11 was characterized in detail.

\section{(e) Analysis of recombinant DNA}

DNAs were cleaved with different restriction endonucleases and were separated by agarose gel electrophoresis. Fragments were transferred to nitrocellulose according to Southern (1975). Individual DNAs $(0.5 \mu \mathrm{g})$ were labeled as described by Rigby et al. (1977) using $1.6 \mathrm{mCi} / \mathrm{ml}$ of $\left[\alpha-{ }^{32} \mathrm{P}\right] \mathrm{dCTP}$ and $\left[\alpha{ }^{32} \mathrm{P}\right] \mathrm{dATP}(6000 \mathrm{Ci} / \mathrm{mmol}$ from Amersham). Hybridization was carried out in $50 \%$ formamide and $5 \times \mathrm{SSC}$ at $42^{\circ} \mathrm{C}$ for $24-48 \mathrm{~h}$. Filters were washed $3 \times 30 \mathrm{~min}$ in $2 \times \mathrm{SSC}$ and $0.5 \%$ SDS at $68^{\circ} \mathrm{C}$.

\section{RESULTS AND DISCUSSION}

\section{(a) Molecular cloning of cDNA complementary to HSRV RNA}

Spumaretrovirus particles were prepared from HEL cell supernatants, purified by sucrose gradient centrifugations, and directly used for synthesis of viral cDNA as described in MATERIALS AND METHODS, section b. To clone HSRV cDNA, it was digested with $E c o$ RI and the fragments were ligated to EcoRI-cleaved $\lambda$ NM1149 DNA (Murray et al., 1983), packaged into phage envelopes and plated on $E$. coli. Plaques were screened by filter hybridization using separately synthesized HSRV $\left[{ }^{32} \mathrm{P}\right] \mathrm{CDNA}$ from sucrose-gradient-purified virions as hybridization probe. Out of 5000 recombinant clones, 180 clones were identified as positive. Several of the positive recombinant clones were cleaved with $E c o$ RI, and the insert DNA was recloned into the $E c o$ RI sites of the plasmid vector pACYC184 and found to hybridize to [ $\left.{ }^{32} \mathrm{P}\right] \mathrm{cDNA}$ (Fig. 1). The resulting recombinant plasmid clones were termed pyHSRV-E-D2, D3, D4 and D6. One of them, D2, was characterized in detail by restriction enzyme and Southern blot analysis (clone 2 in Fig. 3).

Another series of recombinant clones were obtained in an analogous way by using the HindIII instead of the EcoRI enzyme to cleave viral cDNA synthesized in vitro. After ligation and packaging,

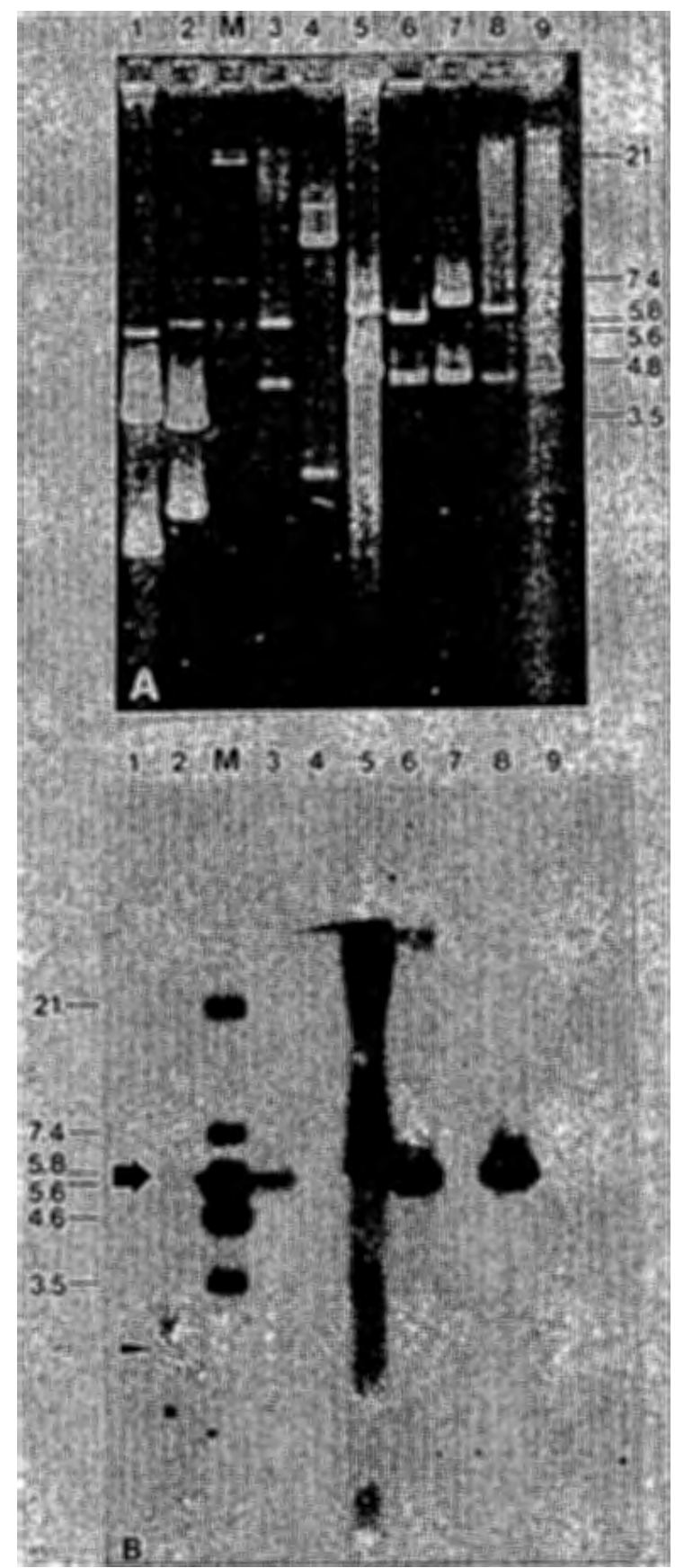

Fig. 1. Southern blot hybridization of different recombinant plasmids to ${ }^{32} \mathrm{P}$-labeled cDNA of the HSRV genome. DNAs from recombinant plasmids constructed from viral DNA (lanes 1 and 2) and from cDNA (lanes 3 to 9) were cleaved with restriction endonucleases BamHI (lane 1, pHSRV-B-34), ClaI (lane 2, pHHRV-B-52), EcoRI (lane 3, pyHSRV-E-C5), Eco RI + HindIII (lane 4, pyHSRV-E-C8), and EcoRI (lanes 5 to 9, pyHSRV-E-D2, D3, D4, D6, and F8, respectively), and separated electrophoretically on $0.8 \%$ agarose gels. Phage $\lambda$ DNA $\left(0.25 \mu \mathrm{g}\right.$ unlabeled and $0.02 \mu \mathrm{g}{ }^{32} \mathrm{P}$-labeled) cleaved with EcoRI served as marker (lanes $\mathrm{M}$ ). (A) EtdBr staining; (B) autoradiogram of the same gel after hybridization to ${ }^{32} \mathrm{P}$-labeled cDNA. Sizes are given in $\mathrm{kb}$ on the margins. The Cla I cleavage pattern of B-52 DNA (lane 2) is the result of a partial digestion, with fragment sizes of $5.5 \mathrm{~kb}$ (thick arrow) and $2.3 \mathrm{~kb}$ (thin arrow). 
five positive plaques were identified from a total of 50 recombinant $\lambda$ phage clones that were screened. The DNA of one clone was cleaved with HindIII, inserted into the HindIII site of the plasmid vector
pAT153, termed pHSRV-H-C55, and was characterized in detail (clone 55 in Fig. 3).

To confirm the viral origin of the recombinant clones obtained, all clones were hybridized to DNA

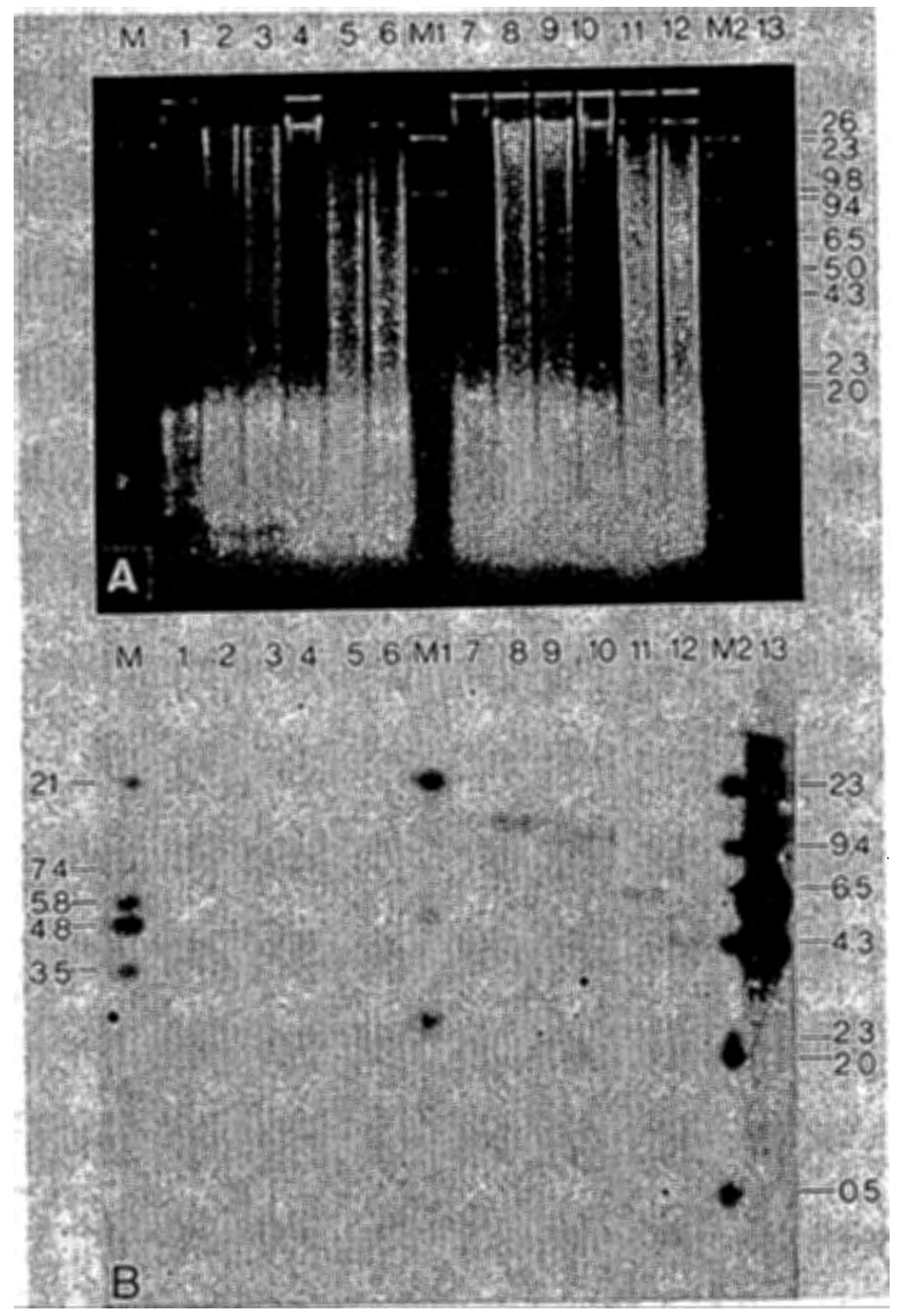

Fig. 2. Southern blot hybridization of recombinant plasmid [ $\left.{ }^{32} \mathrm{P}\right]$ pyHSRV-E-D2 to human genomic DNAs from uninfected and HSRV-infected HEL cells. Deproteinized DNAs ( $5 \mathrm{~g}$ per lane including RNA), obtained from uninfected cells (lanes 1 to 6 ) and from HSRV-infected cells (lanes 7 to 12), were cleaved with restriction endonucleases Asp 718 (lanes 2 and 8), BamHI (lanes 3 and 9), ClaI (lanes 4 and 10), EcoRI (lanes 5 and 11), and HindIII (lanes 6 and 12); untreated DNA (2 $\mu$ g/lane) was run in lanes 1 and 7 . DNA $(0.2 \mu \mathrm{g})$ of pyHSRV-E-D2 digested with $E_{c o} \mathrm{RI}$ (lane 13) was analyzed under the same conditions. Phage $\lambda$ DNA $(0.25 \mu \mathrm{g}$ unlabeled and $0.01 \mu \mathrm{g}^{32} \mathrm{P}$-labeled) cleaved with EcoRI (M), Mlu I(M1), and with HindIII (M2) served as markers and for control of electrophoretic transfer to nitrocellulose paper, (A) EtdBr staining; (B) autoradiogram of the same gel after hybridization to ${ }^{32}$ P-labeled pyHSRV-E-D2 DNA. Sizes are given in $\mathrm{kb}$. 
from mock-infected and HSRV-infected HEL cells that had been digested with various restriction enzymes. Fig. 2 shows the result of these experiments using nick-translated [ $\left.{ }^{32} \mathrm{P}\right] \mathrm{DNA}$ from clone D2. Positive hybridization signals (lanes 7 to 12) were clearly detectable in DNAs from HSRVinfected cells but not in genomes from uninfected cells.

\section{(b) Cloning of HSRV DNA}

Genomic DNA from HSRV-infected HEL cells was digested with Bam HI and screened for HSRVspecific sequences by using ${ }^{32} \mathrm{P}$-labeled recombinant plasmid clones (D2, C55) that had been established from viral cDNA (Fig. 2). Hybridizing Bam HI DNA fragments were isolated, purified by agarose gel electrophoresis, and ligated to $\lambda E M B L 4$ DNA that had been digested with BamHI thereby removing a $19.3 \mathrm{~kb}$ fragment from the $\lambda \mathrm{DNA}$. The ligated DNA was packaged into phage particles and plated on the appropriate $E$. coli host. Two positive plaques out of 30000 recombinant phages screened were identified by hybridizing them to ${ }^{32} \mathrm{P}$-labeled D2 DNA. Several of the resulting recombinant phage clones were cleaved with Bam HI that yielded viral DNA inserts $15-16 \mathrm{~kb}$ in size which were subsequently recloned into the BamHI site of the bacterial plasmid vector pSP65 (Melton et al., 1984). One of these recombinant plasmid clones termed pSPHSRV-B-C11 (clone 11 in Fig. 3) was characterized in detail by restriction enzyme analysis and Southern blot hybridizations (Flugel et al., 1987).

In another set of experiments, a 2.2-kb BamHI DNA fragment that had been prepared from genomic DNA of HSRV-infected HEL cells hybridized to the viral cDNA insert of clone D2. This Bam HI fragment was directly cloned into the BamHI site of the plasmid vector pAT153, termed pHSRV-B-52 (clone 52 in Fig. 3) and analyzed in detail.

\section{(c) Structural analysis of the recombinant clones}

DNA was prepared from each of the recombinant plasmid clones as described in MATERIALS AND METHODS, section c. Purified DNAs were digested

(a)

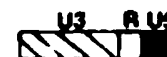

(b)

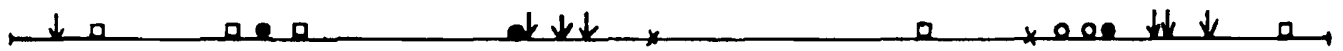

55

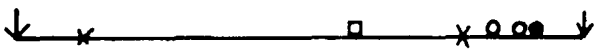

2
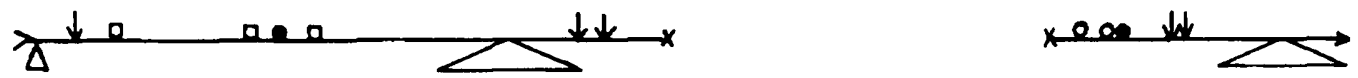

52
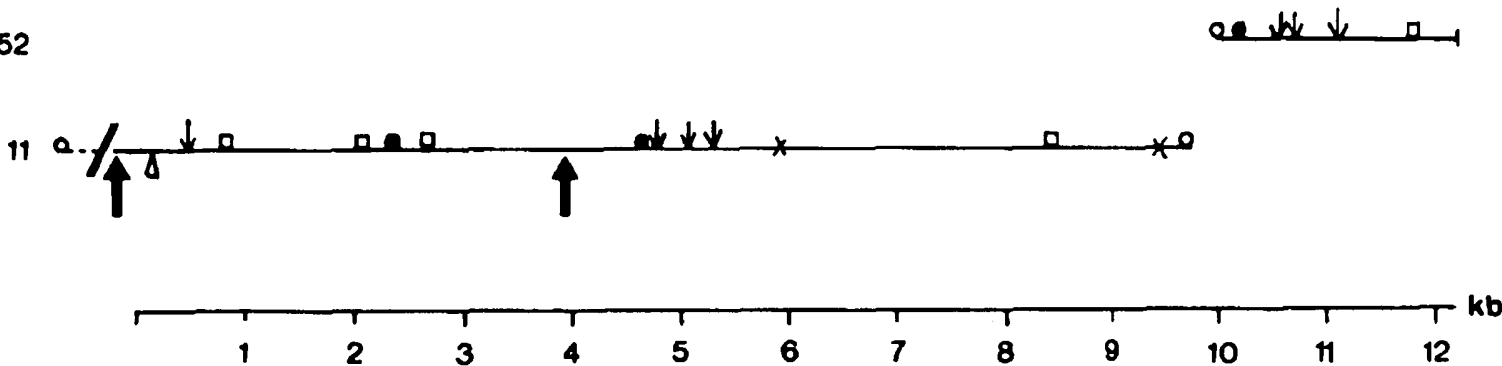

Fig. 3. Restriction maps of linear HSRV DNA and of viral DNA inserts of recombinant plasmid clones. (a) Diagram of linear HSRV DNA. The boxes at the genome termini mark the LTR with the U3 region (hatched), the $R$ region (blank) and the U5 region (blackened). (b) Restriction maps of linear HSRV DNA and of viral DNA inserts of recombinant clones 55, 2, 52, and 11. The symbols are: $\downarrow$, HindIII; $X, E c o R I ; O, B a m H I ; \bigcirc, N c o I$; and $\square, X b a I$. Open triangles below the lines mark deletions within viral nucleotide sequences. The two thick upward arrows mark the 'integration site' of the 5' LTR into the pol gene of clone 11. The map of clone 11 has been reversed to emphasize the colinearity with the other recombinant clones. Note that the scale of the restriction map of clone 11 is broken at the 5 ' end. For further details of structure of clone 11 see RESULTS AND DISCUSSION, section d. 
with various restriction enzymes and analyzed by electrophoresis on agarose gels. Subsequently, the gels were stained with EtdBr (Figs. 4A and 5A), transferred to nitrocellulose and hybridized with ${ }^{32} \mathrm{P}$-labeled recombinant plasmids prepared from cDNA (Fig. 4B,C and Fig. 5B,C). HindIII digestion of clone $\mathrm{C} 55$ yields two fragments of 5.4 and $3.6 \mathrm{~kb}$; the 5.4-kb DNA fragment corresponds to the HSRV-specific DNA insert (Fig. 4B, lane 1). Eco RI cleaved the DNA of clone D2 into two large fragments (Fig. 4, lanes 2) of sizes of 6.4 (viral insert) and $4.0 \mathrm{~kb}$ (vector) (Fig. 4). Further fine mapping revealed that the overlapping regions of clones D2 and C55 are located at the termini of the inserts of both recombinant plasmids as indicated schematically in Fig. 4C. The result was confirmed by nucleotide sequence analysis which proved that the overlap regions encompassed 1225 and $651 \mathrm{nt}$ (Flugel et al., 1987).

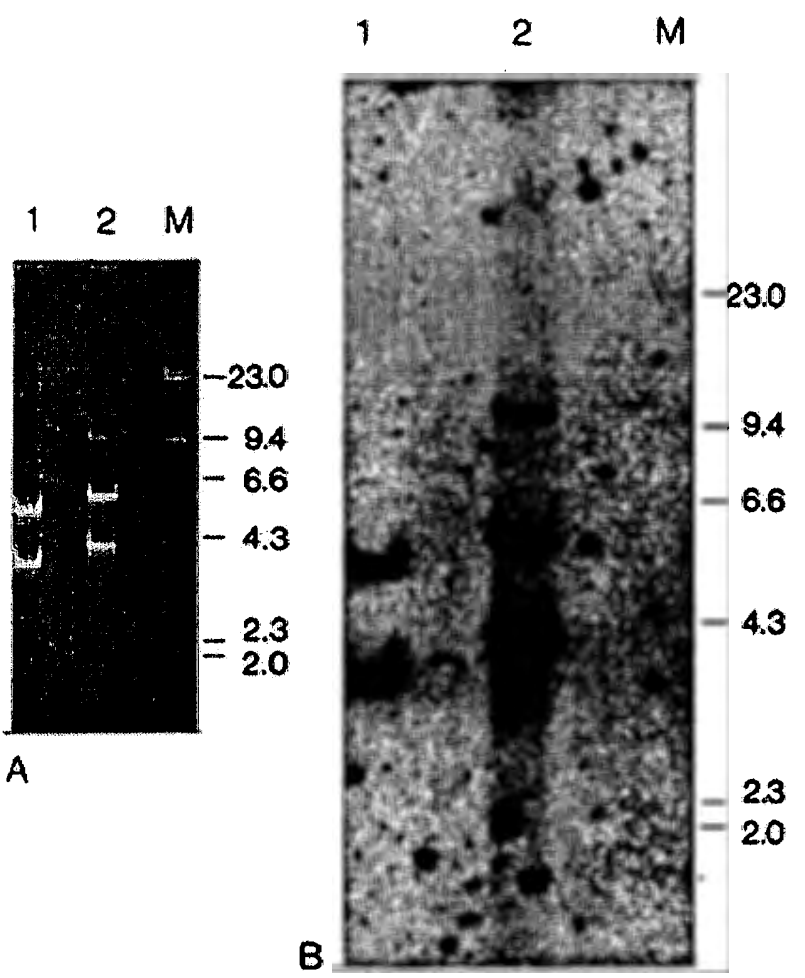

To determine the structure and the nucleotide sequence arrangements of those recombinant plasmid clones that contained even larger viral DNA inserts of $15.4 \mathrm{~kb}$, further blot hybridization analyses were performed using ${ }^{32} \mathrm{P}$-labeled DNA from clones $D 2$ and C55. The results shown in Fig. 5,A to $C$ and Fig. 6,A and $B$ indicate that most of the recombinant clones harbor viral DNA inserts of 15 to $16 \mathrm{~kb}$, since they gave positive hybridization signals with either D2 [ $\left.{ }^{32} \mathrm{P}\right] \mathrm{DNA}$ (Fig. 5B) or with C55 [ $\left.{ }^{32} \mathrm{P}\right] \mathrm{DNA}$ (Fig. 5C). Only one clone was negative (lane 8), whereas another recombinant clone had a relatively small DNA insert of $2.8 \mathrm{~kb}$ that hybridized positively (lane 6). All other recombinant clones (lanes 1 to 5 and 7) can be aligned with the HSRV restriction maps shown in Fig. 3. As a representative example, the restriction fragment cleavage pattern of these recombinant clones obtained after double digestion with BamHI + HindIII is shown in Fig. 6. The viral

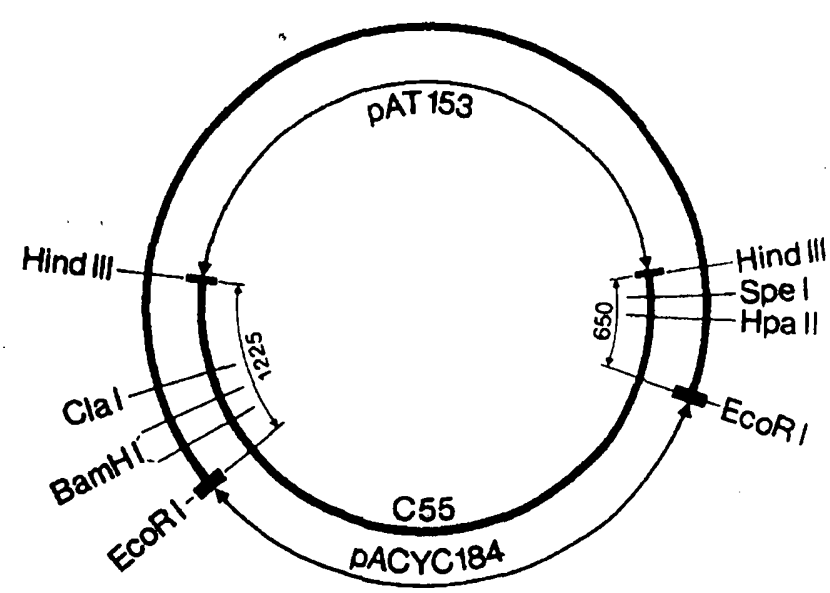

C

Fig. 4. Blot hybridization of recombinant plasmid pHSRV-H-C55 to [32P]pyHSRV-E-D2 (panels A and B), both constructed from cDNA. DNA of C55 (lane 1) was cleaved with HindIII and DNA of D2 (lane 2) was cleaved with EcoRI and separated electrophoretically on a $0.8 \%$ agarose gel. Phage $\lambda$ DNA $(0.25 \mu \mathrm{g}$ unlabeled and $0.02 \mu \mathrm{g}$ labeled) cleaved with $H$ indIII served as marker (M) and for control of electrophoretic transfer to nitrocellulose paper. (A) EtdBr staining; (B) autoradiogram of the same gel after hybridization to ${ }^{32}$ P-labeled pyHSRV-E-D2 DNA. Sizes are given in kb. The EcoRI cleavage pattern of D2 DNA is the result of a partial digestion. (C) Schematic representation of the two recombinant plasmids that harbor overlapping HSRV-specific sequences. Outer ring: pyHSRV-E-D2, the thick line representing the 6.4-kb viral insert; inner ring: pHSRV-H-C55, the thick line represents a 5.4-kb viral insert. All restriction enzymes shown produced DNA fragments of the same size (in bp) in the region overlapping both recombinant clones. The cross bars mark the viral DNA insert-vector boundaries. 


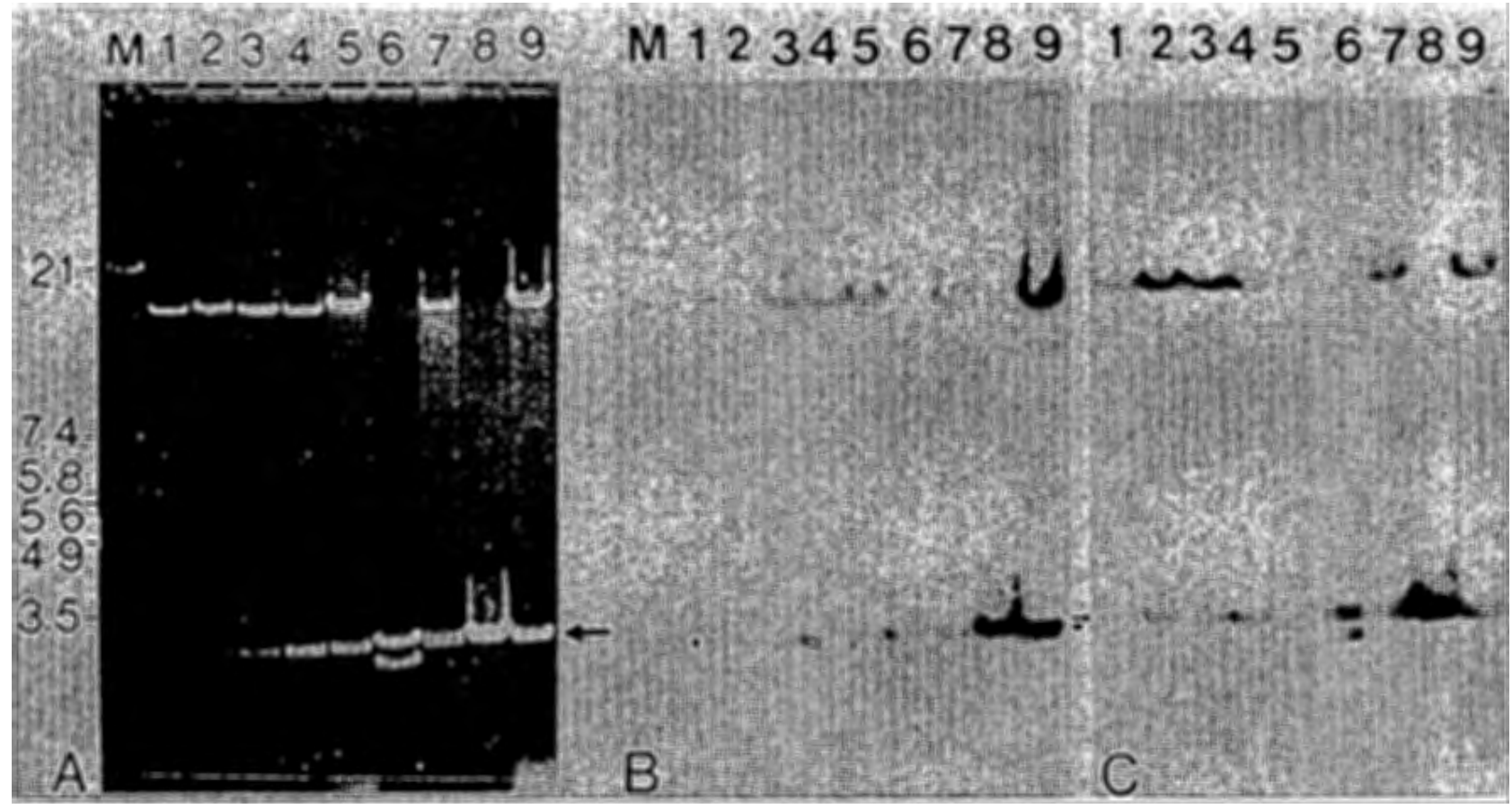

Fig. 5. Gel electrophoresis and Southern blot hybridization of spumaretroviral recombinant DNA clones. DNAs (5 $\mu \mathrm{g})$ were digested with BamHI, separated electrophoretically on a $0.8 \%$ agarose gel, transferred to nitrocellulose and hybridized to ${ }^{32} \mathrm{P}-$ labeled recombinant clones from HSRV cDNA (D2 and C55). (A) EtdBr-stained gel of clones C4, C5, C6, C7, C9, C10, C11, C12, and C13 (lanes 1 to 9). (B) Autoradiograph of the same gel hybridized with ${ }^{32}$ P-labeled clone D2. (C) Autoradiograph of the same gel hybridized with ${ }^{32}$ P-labeled clone C55. The lanes $M$ are EcoRI fragments of phage $\lambda$ DNA with the sizes given on the left-hand margin of panel A. The arrows indicate position of pSP65 vector DNA.

DNA insert of clone 11 is $15.4 \mathrm{~kb}$ in size (Fig. 5 , lane 7) and a HindIII-BamHI subfragment of this clone hybridized and co-migrated with the HindIIIBamHI DNA fragment of recombinant clone C55 (Fig. 6A, lane 10 and Fig. 6B). This result indicates that the HindIII-BamHI DNA fragments of both clones, $\mathrm{C} 11$ and $\mathrm{C} 55$, are colinear on the HSRV map (Fig. 3). This interpretation was verified by nucleotide sequence analysis (Flugel et al., 1987).

Similar mapping experiments and nucleotide sequence analyses confirmed the restriction maps of all recombinant clones shown in Fig. 3. Clone 52 DNA is particularly interesting, since its viral DNA insert of $2.2 \mathrm{~kb}$ is located at the $3^{\prime}$ end of the HSRV map and, as revealed by nucleotide sequencing, contains the complete $3^{\prime}$ LTR. Fig. 1 shows that clone 52 DNA hybridized to [ ${ }^{32} \mathrm{P}$ ]cDNA. Although recombinant clone 52 was isolated from the Bam HI digest of genomic DNA of virus-infected human cells and cloned into the BamHI site of pAT153, the viral DNA insert could not be cut out by digesting the clone B52 DNA with BamHI. Nucleotide sequence analysis of the recombinant clone demonstrated that one of the BamHI sites (the 5'-BamHI site in Fig. 3) had been retained but the second BamHI (at the $3^{\prime}$ end) was not present (Flugel et al., 1987).

\section{(d) Conclusions}

Spumaretroviral DNA has been molecularly cloned into various restriction enzyme sites of two different $\lambda$ vectors and several bacterial plasmid vectors. Two completely independent sources of HSRV DNA were used as starting material for molecular cloning cDNA and viral DNA from total genomic DNA of HSRV-infected cells. The viral DNA inserts of the resulting recombinant cloner hybridized to each other and displayed colinear restriction maps having LTRs at the ends of the genome. These results demonstrate that the complete HSRV genome is represented by the recombinant plasmid clones obtained. 


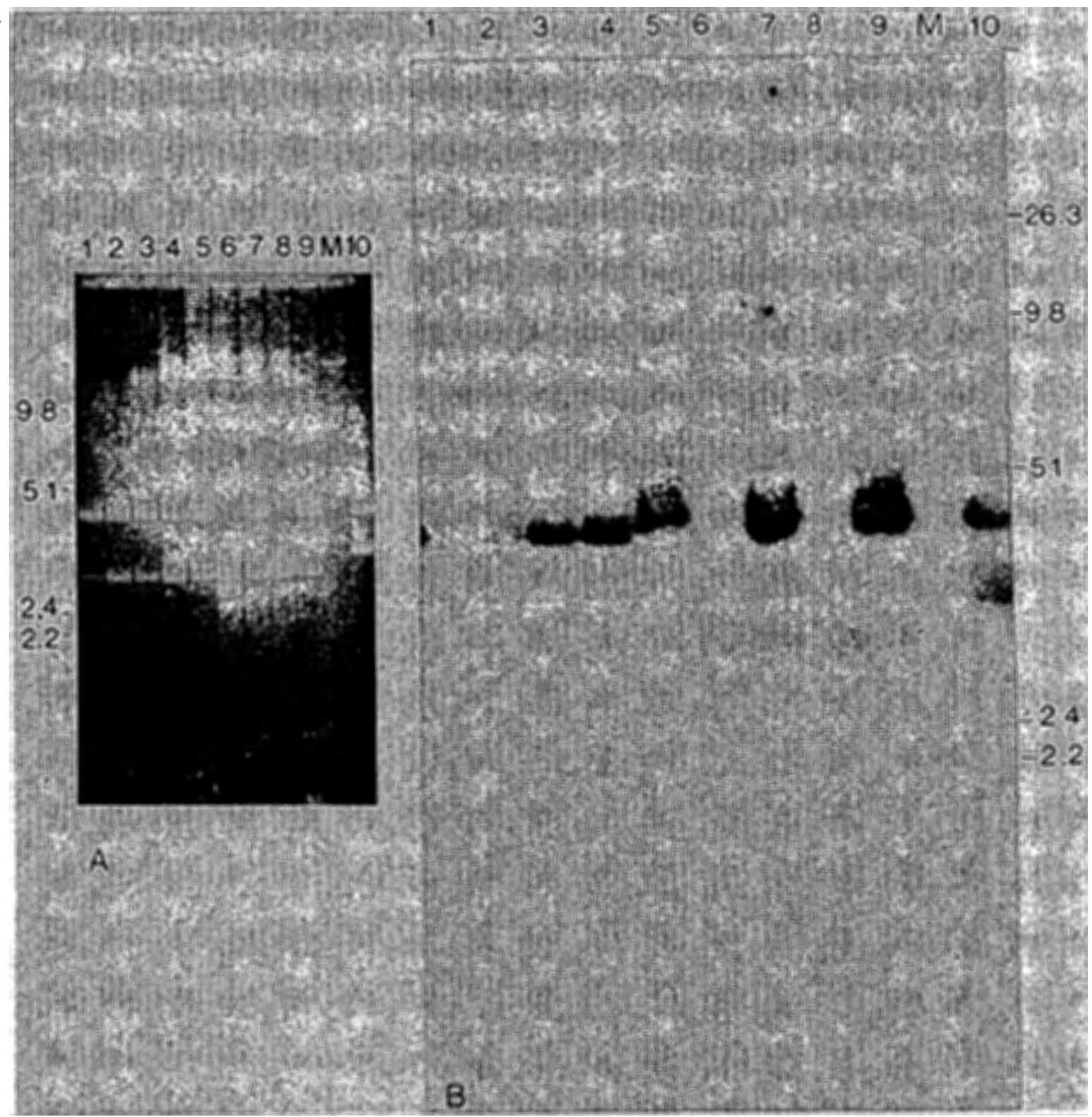

Fig. 6. Gel electrophoresis and Southern blot analysis of spumaretroviral recombinant DNA clones. DNAs $(5 \mu \mathrm{g})$ were double-digested with Bam HI + HindIII, separated electrophoretically on a $0.8 \%$ agarose gel, transferred to nitrocellulose and hybridized to ${ }^{32} \mathrm{P}-$ labeled recombinant clones that had been established from HSRV cDNA. (A) EtdBr-stained gel of clones C4, C5, C6, C7, C9, C10, C11, C12, and $\mathrm{Cl} 3$ (lanes 1 to 9). (B) Autoradiograph of the same gel hybridized to ${ }^{32} \mathrm{P}$-labeled clone C55. M marks the $\mathrm{MluI}$ fragments from phage $\lambda$ DNA. ${ }^{32}$ P-labeled DNA from recombinant clone C55 was double-digested with Bam HI + HindIII (lane 10).

However, some of the clones had sustained internal deletions. For example, clone D2 that was cloned from HSRV cDNA contains three deletions of different sizes as determined by nucleotide sequence analyses of different HSRV recombinant clones (Flugel et al., 1987). One deletion of 1230 bp was found to be located in the pol region (in the central part of the reverse transcriptase domain), the other two deletions were in the LTR. These studies cannot determine how these deletions were generated. There have been several reports on deletions that occurred during molecular cloning of retroviral and specially lentiviral DNA (Molineaux and Clements, 1983; Hahn et al., 1984). Since the deletions of clone D2 in the pol gene and the LTR are flanked by a short repeat sequence, one can assume that they have oc- 
curred during molecular cloning. Alternatively, the event could have happened during in vitro cDNA synthesis. This conclusion rests on the primary structure of clone D2 DNA and in addition is based on the assumption that during cDNA synthesis in vitro, a full-length, double-stranded DNA was generated containing one LTR only which subsequently underwent deletions. Proviral DNAs with one LTR have been isolated and characterized previously ( $\mathrm{Ju}$ and Skalka, 1980).

Recombinant clone 11 that was established from viral DNA has an unusual and remarkable structure. Restriction fine mapping of $\mathrm{C} 11$ revealed that a recombination and/or integration event had occurred into the pol region of this clone. Nucleotide sequence analysis unequivocally showed that another HSRV DNA had been inserted close to map position of 3.9 kb (Fig. 3). Thus, the 5' LTR of the 'integrated' HSRV starts at this map position, the viral genome running backwards continues to the Bam HI site that is located $5.6 \mathrm{~kb}$ upstream from this 'integration' point. The mechanism for this event is unknown.

In conclusion, recombinant plasmid clones have been established for the complete HSRV genome. The recombinant clones will be useful for the analysis of the structure of spumaretroviral genes and expression of their gene products. They will be invaluable as a new diagnostic sequence to probe patients with various diseases of suspected viral etiology.

\section{ACKNOWLEDGEMENTS}

We thank Dr. Peter Gruss for critically reading the manuscript. This work was supported by a postdoctoral training stipend (627-1-1) from the Deutsche Forschungsgemeinschaft.

\section{REFERENCES}

Chang, A.C.Y. and Cohen, S.N.: Construction and characterization of amplifiable multicopy DNA cloning vehicles derived from the P15A cryptic miniplasmid. J. Bacteriol. 134 (1978) 1141-1156.

Flügel, R.M., Rethwilm, A., Maurer, B. and Darai, G.: Nucleotide sequence analysis of the env gene and its flanking regions of the human spumaretrovirus reveals two novel genes. EMBO J. 6 (1987) 2077-2084.

Frischauf, A.-M., Lehrach, H., Poustka, A. and Murray, N.: Lambda replacement vectors carrying polylinker sequences. J. Mol. Biol. 170 (1983) 827-842.

Gajdusek, D.C.: Unconventional viruses and the origin and disappearance of Kuru. Science 197 (1977) 943-960.

Gubler, U. and Hoffman, B.J.: A simple and very efficient method for generating cDNA libraries. Gene 25 (1983) 263-269.

Hahn, B.H., Shaw, G.M., Arya, S.K., Popovic, M., Gallo, R.C. and Wong-Staal, F.: Molecular cloning and characterization of the HTLV-III virus associated with AIDS. Nature 312 (1984) 166-169.

Hohn, B.: In vitro packaging of lambda and cosmid DNA. Methods Enzymol. 68 (1979) 299-310.

Hooks, J.J. and Detrick-Hooks, B.: Spumavirinae: foamy virus group infections; comparative aspects and diagnosis. In Kurstak, E. and Kurstak, C. (Eds.) Comparative Diagnosis of Viral Diseases, Vol. IV. Academic Press, New York, 1981, pp. 599-617.

Ju, G., Boone, L. and Skalka, A.-M.: Isolation and characterization of recombinant DNA clones of avian retroviruses: size heterogeneity and instability of the direct repeat. J. Virol. 33 (1980) 1026-1033.

Ju, G. and Skalka, A.-M.: Nucleotide sequence analysis of the long terminal repeat (LTR) of avian retroviruses: structural similarities with transposable elements. Cell 22 (1980) 379-386.

Loh, P.C. and Ang, K.S.: Replication of human syncytiumforming virus in human cells: effects of certain biological factors and selective chemicals. J. Med. Virol.'7 (1981) 67-73.

Maniatis, T., Fritsch, E.F. and Sambrook, J.: Molecular Cloning. A Laboratory Manual. Cold Spring Harbor Laboratory, Cold Spring Harbor, NY, 1982, pp. 194-195.

Melton, D.A., Krieg, P.A., Rebagliati, M.R., Maniatis, T., Zinn, K. and Green, M.R.: Efficient in vitro synthesis of biologically active RNA and RNA hybridization probes from plasmids containing a bacteriophage SP6 promoter. Nucl. Acids Res. 12 (1984) 7035-7056.

Molineaux, S. and Clements, J:E.: Molecular cloning of unintegrated visna viral DNA and characterization of frequent deletions in the $3^{\prime}$ terminus. Gene 23 (1983) 137-148.

Muller, H.K., Ball, G., Epstein, M.A., Achong, B.G., Lenoir, G. and Levin, A.: The prevalence of naturally occurring antibodies to human syncytial virus in East African populations. J. Gen. Virol. 47 (1980) 399-406.

Murray, N.: Phage lambda and molecular cloning. In Hendrix, R.W., Roberts, J.W., Stahl, F.W. and Weisberg, R.A. (Eds.) Lambda II. Cold Spring Harbor Laboratory, Cold Spring Harbor, NY, 1983, 395-432.

Nara, P.L., Robey, W.G., Arthur, O.O., Gonda, M.A., Asher, D.M., Yanagihara, R., Giss Jr., C.J., Gajdusek, D.C. and Fischinger, P.J.: Simultaneous isolation of simian foamy virus and HTLV-III/LAV from chimpanzee lymphocytes following HTLV-III or LAV inoculation. Arch. Virol. 92 (1987) 183-186. 
Neumann-Haefelin, D., Rethwilm, A., Bauer, G., Gudat, F. and zur Hausen, H.: Characterization of a foamy virus isolated from Cercopithecus aethiops lymphoblastoid cells. Med. Microbiol. Immunol. 172 (1983) 75-86.

Obara, T., Bolognesi, D.P. and Bauer, H.: Ribosomal RNA in avian leukosis virus particles. Int. J. Cancer 7 (1971) 535-546.

Rigby, P.W.J., Dieckmann, M., Rhodes, C. and Berg, P.: Labeling deoxyribonucleic acid to high specific activity in vitro by nick translation with DNA polymerase I. J. Mol. Biol. 114 (1977) 237-256.

Rogers, N.G., Basnight, M., Gibbs Jr., C.J. and Gajdusek, D.C.: Latent viruses in chimpanzees with experimental Kuru. Nature 216 (1987) 446-449.

Rothenberg, E. and Baltimore, D.: Synthesis of long, representative DNA copies of the murine RNA tumor virus genome. J. Virol. 17 (1976) 168-174.
Southern, E.M.: Detection of specific sequences among DNA fragments separated by gel electrophoresis. J. Mol. Biol. 98 (1975) 503-517.

Taylor, J.M., IUmensee, R. and Summers, J.: Efficient transcription of RNA into DNA by avian sarcoma virus polymerase. Biochim. Biophys. Acta 442 (1976) 324-330.

Twigg, A. and Sheratt, D.: Trans-complementable copy-number mutants of plasmid ColEl. Nature 283 (1980) 216-218.

Weiss, R., Teich, N., Varmus, H. and Coffin, J.: Taxonomy of spumaviruses. In Weiss, R., Teich, N., Varmus, H. and Coffin J. (Eds.) RNA Tumor Viruses, 2nd ed. Cold Spring Harbor Laboratory, Cold Spring Harbor, NY, 1982, pp. 157-207.

Communicated by T. Hohn. 